\title{
UPAYA MENINGKATKAN KINERJA GURU DALAM PELAKSANAAN PEMBELAJARAN DI KELAS DENGAN MELAKSANAKAN SUPERVISI AKADEMIK DI SEKOLAH DASAR KATOLIK WAEPANA, KECAMATAN SOA, KABUPATEN NGADA TA 2018/2019
}

\author{
Waku Yasinta \\ Kepala SDK Waepana
}

\begin{abstract}
Tujuan penelitian tindakan sekolah ini adalah untuk meningkatkan kinerja guru dalam pelaksanaan pembelajaran di SDK Waepana, Kecamatan Soa. Jenis penelitian yang digunakan dalam penelitian ini adalah penelitian tindakan sekolah. Kegiatan dalam penelitian ini terdiri atas tahapan perencanaan tindakan, pelaksanaan tindakan,observasi, dan refleksi. Penelitian ini dilakukan dalam dua siklus. Tempat penelitian di SDK Waepana, Kecamatan Soa, Kabupaten Ngada. Subyek dalam penelitian ini adalah guru - guru di SDK Waepana yang berjumlah 9 orang, yang terdiri dari 6 orang guru kelas dan 3 orang guru mata pelajaran. Metode pengumpulan data menggunakan metode obeservasi kelas. Analisis data yang digunakan adalah teknik analisis deskriptif komparatif. Data kuantitatif yang diperoleh dideskripsikan dalam bentuk kata-kata atau penjelasan. Selanjutnya dilakukan komparasi data untuk memastikan ada tidaknya peningkatan kinerja guru dalam pelaksanaan pembelajaran di Kelas. Dari rata-rata nilai supervise akademik guru dalam pelaksanaan pembelajaran di kelas pada kondisi awal diperoleh $63 \%$. Pada ahir Siklus I rata - rata nilai yang diperoleh $79,89 \%$, di akhir siklus II diperoleh 88, 33\%, dan dari kondisi awal sampai dengan akhir siklus II nilai supervisi akademik meningkat sebesar 25,33\%. Hal ini dapat disimpulkan bahwa dengan Pelaksanaan Supervisi akademik, maka dapat meningkatkan kinerja guru dalam pelaksanaan pembelajaran di SDK Waepana, Kecamatan Soa, Kabupaten Ngada TA 2018/2019.
\end{abstract}

Kata kunci: supervisi akademik, kinerja guru, pelaksanaan pembelajaran 


\section{PENDAHULUAN}

Peran dan tanggung jawab guru pada masa mendatang akan semakin kompleks, sehingga menuntut guru untuk senantiasa melakukan berbagai peningkatan dan penyesuaian kemampuan profesionalnya. Guru harus lebih dinamis dan kreatif dalam mengembangkan proses pembelajaran peserta didik. Guru di masa mendatang tidak lagi menjadi satu-satunya orang yang paling well informed (berpengatahuan luas) terhadap berbagai informasi dan pengetahuan yang sedang tumbuh, berkembang, berinteraksi dengan manusia di jagat raya ini.

Untuk mengetahui pelaksanaan fungsi dan tugas guru dalam kegiata pembelajaran perlu dilakukan supervisi akademik.

Menurut Rasdi Ekosiswoyo, 2008 supervisi adalah sebagai proses pemberi bantuan, umpan balik, pelayanan, peng-awasan, pembinaan, bimbingan, pember-dayaan, dorongan, pengaruh baik, secara perorangan maupun kelompokdari superor-dinasi kepada subordinasi agar supaya proses pembelajaran dapat berlangsung sebagaimana mestinya dan hasil-hasinya lebih baik/meningkat. Dalam kegiatan super-vise ada dua, yaitu supervise akademik dan supervise manajerial.

Supervisi akademik dapat dilakukan oleh pengawas, kepala sekolah, dan guru yang ditugasi oleh kepala sekolah untuk melakukan tugas sebagai penyelia.

Dan untuk membantu para penyelia melaksanakan supervisi akademik yang terprogram, terarah, dan berkesinambungan, APSI Pusat telah mengembangkan Instrumen Supervisi (IS) Akademik. Format IS Akademik ini meliputi tiga bagian yang digunakan sebelum pengamatan (pra observasi),

selampengamatan (observasi) dan setelah pengamatan pembelajaran (Pasca observasi).

Dengan mengacu instrumen supervisi akademik ini, diiharapkan penyelia dapat melaksanakan supervisi akademik secara klinis melalui pendekatan kemitraan (collegial) dengan siklus perencanaan yang sistematis, pengamatan yang cermat, dan umpan balik yang objektif dan segera, untuk memberikan bantuan teknis kepada guru dalam melaksanakan pembelajaran yang efektif, efisien dan berkualitas. Kata 
kunci dalam supervisi pengajaran (akademik) bukanlah pengawasan, namun bantuan pada guru untuk meningkatkan pembelajaran.

Pelaksanaan supervise akademik adalah salah satu upaya yang dilakukan dalam menngkatkan kinerja guru dalam pelaksanaan pembelajaran. Istilah kinerja dimaksudkan sebagai terjemahan dari istilah "performance". Kane (dalam Awe; 2014) berpendapat bahwa kinerja bukan merupakan karakteristik seseorang, seperti bakat atau kemampuan, tetapi merupakan perwujudan dari bakat atau kemampuan itu sendiri. Pendapat tersebut menunjukkan bahwa kinerja merupakan perwujudan dari kemampuan dalam bentuk karya nyata. Kinerja dalam kaitannya dengan jabatan diartikan sebagai hasil yang dicapai yang berkaitan dengan fungsi jabatan dalam periode waktu tertentu. Kinerja guru mempunyai spesifikasi tertentu. Kinerja guru dapat dilihat dan diukur berdasarkan spesifikasi atau kriteria kompetensi yang harus dimiliki oleh setiap guru. Berkaitan dengan kinerja guru, wujud perilaku yang dimaksud adalah kegiatan guru dalam proses pembelajaran.

Penilaian kinerja guru merupakan suatu proses yang bertujuan untuk mengetahui atau memahami tingkat kinerja guru satu dengan tingkat kinerja guru yang lainnya atau dibandingkan dengan standar yang telah ditetapkan.

Handoko (1994: 135) menjelaskan bahwa, "penilaian prestai kerja (performance appraisal) adalah proses melalui mana organisasiorganisasi mengevaluasi atau menilai prestasi kerja karyawan". Penilaian kinerja pada dasarnya merupakan faktor kunci guna mengembangkan suatu organisasi secara efektif dan efisien, karena adanya kebijakan atau program yang lebih baik atas sumber daya manusia yang ada dalam organisasi. Terdapat berbagai model instrumen yang dapat dipakai dalam penilaian kinerja guru

Sergiovanni (1987) menegaskan bahwa refleksi praktis penilaian kinerja guru dalam supervisi akademik adalah melihat kondisi nyata kinerja guru untuk menjawab pertanyaanpertanyaan,misalnya apa yang sebenarnya terjadi di dalam kelas?, apa yang sebenarnya dilakukan oleh 
guru dan siswa di dalam kelas?, aktivitas-aktivitas mana dari keseluruhan aktivitas di dalam kelas itu yang bermakna bagi guru dan murid?, apa yang telah dilakukan oleh guru dalam mencapai tujuan akademik?, apa kelebihan dan kekurangan guru dan bagaimana cara mengembangkannya?. Berdasarkan jawaban terhadap pertanyaan pertanyaan ini akan diperoleh informasi mengenai kemampuan guru dalam mengelola pembelajaran. Namun satu hal yang perlu ditegaskan di sini, bahwa setelah melakukan penilaian kinerja bukan berarti selesailah pelaksanaan supervisi akademik, melainkan harus dilanjutkan dengan tindak lanjutnya berupa pembuatan program supervisi akademik dan melaksanakannya dengan sebaik-baiknya.

Hasil supervisi perlu ditindak lanjuti agar memberikan dampak yang nyata bagi peningkatkan profesionalisme guru. Dampak nyata ini diharapkan dapat dirasakan masyarakat maupun stakeholders. Tindak lanjut tersebut berupa: penguatan dan penghargaan diberikan kepada guru yang telah memenuhi standar, teguran yang bersifat mendidik diberikan kepada guru yang belum memenuhi standar dan guru diberi kesempatan untuk mengikuti pelatihan/penataran lebih lanjut.

Berdasarkan uraian diatas, kenyataan yang terjadi di SDK Waepana, di lihat dari kelayakan mengajar, semua guru layak, karena sudah memenuhi standar minimal lulusan, yaitu S1 (strata satu ). Namun masalahnya adalah masih banyak yang memiliki kemampuan pas-pasan. Indikator dari hal tersebut adalah rendahnya mutu hasil pembelajaran. Memang faktor penentu keberhasilan pembelajaran tidak hanya ditentukan oleh guru saja. Akan tetapi, guru memegang peranan yang sangat dominan, sangat penting, dan sangat menentukan.

Disisi lain berdasarkan pengamatan, masih banyak guru yang tidak melaksanakan tugas pokok dan fungsinya dengan baik. Kita tahu bahwa berdasarkan Peraturan Pemerintah Nomor 74 tahun 2008, tentang Guru Pasal 52 ayat (1) mencakup kegiatan pokok yaitu merencanakan pembelajaran, melaksanakan pembelajaran, menilai hasil pembelajaran, membimbing dan 
melatih peserta didik, serta melaksanakan tugas tambahan yang melekat pada pelaksanaan tugas pokok. Akan tetapi kenyataanya tidak semua guru melakukan itu. Guru mengajar tanpa persiapan, perencanaan, dan tindak lanjut. Masih banyak guru yang belum bisa menyusun rencana pembelajaran, memilih metode, media, dan model pembelajaran dengan baik, sehingga dapat kita bayangkan bagaimana hasil pembelajarannya. Sudah barang tentu tujuan pembelajaran yang telah diamanatkan oleh undang-undang tidak akan tercapai.

Disiplin guru pun rendah. Tidak sedikit guru yang datang terlambat dan pulang belum waktunya. Hadirnya di sekolah pun tidak langsung melaksanakan tugas dengan baik. Duduk santai, ngobrol dan masih banyak sikap perilaku guru yang tidak menunjukkan profesionalitas. Jika kondisi ini dibiarkan maka kehancuran mutu pendidikan pasti akan datang. Sebagai usaha untuk menangani kendala diatas, salah satu upaya yang dilakukan dalam perbaikan kinerja guru dianggap perlu untuk menerapkan supervisi akademik. Supervisi bertujuan memperbaiki situasi belajar mengajar yang lebih baik di mana terjadi proses interaksi antara guru dengan siswa dalam upaya mencapai tujuan pembelajaran yang telah ditentukan yaitu pembentukan pribadi anak yang mandiri sesuai dengan tuntutan perubahan zaman. Berdasarkan uraian dan permasalahan di atas, maka tujuan dalam penelitian adalah "untuk meningkatkan kinerja guru dalam melaksanakan kegiatan penmbelajaran melalui pelaksanaan supervise akademik pada guru - guru di SDK Waepana, Kecamatan Soa, Kabupaten Ngada, TA 2018/2019

\section{METODE PENELITIAN}

Penelitian ini berbentuk Penelitian Tindakan Sekolah (School Action Research), yaitu sebuah penelitian yang merupakan kerjasama antara peneliti dan guru, dalam meningkatkan kinerja guru agar menjadi lebih baik dalam pelaksanaan pembelajaran .

Penelitian Tindakan Sekolah ini dilaksanakan selama kurang lebih tiga bulan mulai Agustus sampai dengan Oktober 2018. Penelitian Tindakan Sekolah dilaksanakan di SDK 
Waepana, Kecamatan Soa, Kabupaten Ngada.

Yang menjadi subyek dalam PTS ini adalah guru kelas SDK waepana yang berjumlah 9 orang. Objek penelitian ini pelaksanaan supervisi akademik oleh kepala sekolah.

Prosedur Penelitian ini dilakukan berdasarkan tahap-tahap penelitian yaitu; Perencanaa, Pelaksanaan, Observasi dan refleksi. Penlitian ini dilaksanaka dalam dua siklus.

Metode atau teknik pengumpulan data menggunakan teknik obeservasi selama proses tindakan penelitian oleh supervisor. Instrument yang digunakan adalah pedoman observasi. Instrumen observasi yang digunakan berupa alat penilaian kompetensi guru (APKG) penilaian dalam pelaksanaan Pembelajaran yang terdiri dari Pedoman Observasi Penilaian Rencana Pelaksanaan Pembelajaran (RPP) dan Pedoman Observasi Penilaian Pelaksanaan Pembelajaran

Analisis data yang digunakan adalah teknik analisis deskriptif komparatif. Data kualitatif yang diperoleh dideskripsikan dalam bentuk kata-kata atau penjelasan.
Selanjutnya dilakukan komparasi data untuk memastikan ada tidaknya peningkatan kinerja guru. Kinerja guru yang dimaksudkan dalam penelitian ini adalah kemampuan guru dalam pelaksanaan pembelajaran. Sebagai tolok ukur keberhasilan pelaksanaan penelitian tindakan sekolah ini ditetapkan indikator kinerja yaitu persentase jumlah skor perolehan Kinerja Guru dalam pelaksanaan pembelajaran sebesar $25 \%$.

Tiap instrumen penilaian terdapat 5 kualifikasi penilaian yaitu 1, 2, 3, 4 dan 5 Setiap skor yang diperoleh kemudian dibagi dengan skor maksimal dan dikalikan dengan 100 atau

$$
\mathrm{N}=\frac{\text { skor yang diperoleh }}{\text { skor maksimal }} \times 100
$$

Adapun kriteria penilaian yaitu: Baik Sekali berada di skor 91 sampai 100 , Baik berada pada skor 76 sampai 90 , Cukup berada pada skor 61 sampai 75 , Kurang berada pada skor 51 sampai 60 sedangkan Kurang Sekali berada pada skor kurang dari 50 .

\section{HASIL DAN PEMBAHASAN}

Penelitian ini dilaksanakan di SDK Waepana, Kecamatan Soa, 
Kabupaten Ngada dengan

melaksanakan supervise akademik pada 9 orang guru. Tindakan peneliti dalam pembinaan atau supervisi pada kondisi awal belum menggunakan model supervisi akademik. Keadaan yang demikian mengakibatkan kurangnya perhatian para guru terhadap tugas dan fungsi sebagai guru, salah satunya melaksanakan pembelajaran yanh baik dan benar, yang dilakukan hanya untuk persyaratan kenaikan pangkat. Dengan demikian akan menimbulkan rendahnya kompetensi guru dalam melaksanakan pembelajaran.

Untuk itu pada kegiatan penelitian siklus I dan II dilaksanakan kegiatan supervise akademik sebagai upaya peningkatankinerja guru dalam pelaksanaan pembelajaran di kelas. Hasil pelaksanaan Supervisi akademik pada siklus I dan II serta peningkatan Kinerja guru dalam pelaksanaan pembelajaran dari kondisi awal hingga pelaksanaan tindakan siklus I dan II dapat dilihat pada tabel di bawah ini.

\section{Tabel 1 Hasil Supervisi Akademik Siklus I dan II}

\begin{tabular}{|c|c|c|}
\hline Kegiatan & Nilai Rata & Peningkatan \\
& - Rata & \\
& Nilai & \\
& Supervisi & \\
\hline
\end{tabular}

\begin{tabular}{|l|c|c|}
\hline $\begin{array}{l}\text { Kondisi } \\
\text { Awal }\end{array}$ & $63 \%$ & - \\
\hline Siklus I & $79,89 \%$ & $16,89 \%$ \\
\hline Siklus II & $88,33 \%$ & $8,44 \%$ \\
\hline $\begin{array}{l}\text { Rat - Rata } \\
\text { peningkatan }\end{array}$ & $25,33 \%$ \\
\hline
\end{tabular}

Dari data dalam tabel diatas, diperoleh temuan: a) pada kondisi awal, rata-rata nilai supervise akademik kinerja guru dalam menyusun dan pelaksanaan pembelajaran dal mencapai $63 \%$ (skor maksimal ideal 100); b) setelah diberikan tindakan, rata-rata kinerja guru dalam melaksanakan pembelajaran sebesar 89,6 \%. Data ini menunjukkan peningkatan kinerja guru dalam meyusun administrasi pembelajaran dan pelaksanaan pembelajaran yang diperoleh lewat supervise akademik sebesar 25,33\%. Dan penelitian ini dikatakan berhasil karena melebihi indikator peningkatan kinerja sebesar $25 \%$ Tabel berikutnya memberikan gambaran distribusi dan visualisasi skor kondisi awal dan setelah diberi tindakan.

Dalam penelitian ini, peneliti memilih supervise akademik sebagai upaya untuk meningkatkan kinerja guru. Kinerja Guru yang dimaksud dalam penelitian ini adalah kemampuan Guru dalam menyiapkan administrasi pembelajaran yaitu 
menyusun RPP, dan Implementasi guru dalam kegiatan pembelajaran dikelas. Pelaksanaan Supervisi akademik dipandang perlu sehingga dapat mengetahui kualitas gutru dan kemampuan guru dalam melaksanakan tugas dan fungsunya dalam kegiatan pembelajaran di kelas. Supervisi yang dilakukan dalam penelitian ini adalah supervise yang dilakukan oleh kepala sekolah kepadsa 9 orang guru yaitu 6 guru kelas dan 3 orang guru mata pelajaran di SDK waepana, Kecamatan Soa, Kabuten Ngada. Yang dilakukan pada bulan Agustus hingga bulan Oktober 2018.

Dari data dalam tabel diatas, diperoleh temuan: a) pada kondisi awal, rata-rata nilai supervise akademik kinerja guru dalam menyusun dan pelaksanaan pembelajaran dal mencapai $63 \%$ (skor maksimal ideal 100); b) setelah diberikan tindakan, rata-rata kinerja guru dalam menyusun dan melaksanakan pembelajaran sebesar $89,6 \%$ Data ini menunjukkan peningkatan kinerja guru dalam meyusun administrasi pembelajaran dan pelaksanaan pembelajaran yang diperoleh lewat supervise akademik sebesar 25,33\%. Dan penelitian ini dikatakan berhasil karena melebihi indikator peningkatan kinerja sebesar $25 \%$.

Dari data yang diperoleh kinerja guru dalam penyusunan administrasi pembelajaran dan pelaksanaan kegiatan mengalami peningkatan, dari kondisi awal hingga di kondisi akir pelaksanaan Tindakan siklus II dengan menerapkan supervise akademik. Dan sesuai dengan Patokan acuan penilianan berada pada rentangan 76 - $90 \%$ berada pada kategori baik.

Temuan ini mengindikasikan adanya peningkatan kinerja guru dalam penyusunan administrasi pembelajaran dan pelaksanaan pembelajaran. Besaran peningkatan 25,33 Jika dibandingkan dengan indikator kinerja 25\% ternyata temuan tersebut telah mencapai keberhasilan.

Melalui pelaksanaan supervisi akademik memberikan motivasi kepada guru dalam upaya meningkatakan kompetensi dan keprofesionalan guru dalam pelaksanaan pembelajaran dikelas. Pelaksanaan tugas utama guru tidak dapat dipisahkan dari kemampuan 
seorang guru dalam penguasaan

pengetahuan, penerapan

pengetahuan dan keterampilan,

sebagai kompetensi yang dibutuhkan

sesuai amanat Peraturan Menteri

Pendidikan Nasional Nomor 16 Tahun

2007 tentang Standar Kualifikasi

Akademik dan Kompetensi Guru.

Sistem Penilaian Kinerja Guru adalah sistem penilaian yang dirancang untuk mengidentifikasi kemampuan guru dalam melaksanakan tugasnya melalui pengukuran penguasaan kompetensi yang ditunjukkan dalam unjuk kerjanya. Hasil Penilaian kinerja guru diharapkan dapat bermanfaat untuk menentukan berbagai kebijakan yang terkait dengan peningkatan mutu dan kinerja guru sebagai ujung tombak pelaksanaan proses pendidikan dalam menciptakan insan yang cerdas, komprehensif, dan berdaya saing tinggi.

Penilaian Kinerja Guru dilakukan Melalui supervise akademik. Melalui supervise akademik, guru dapat mengevaluasi diruinya. Evaluasi diri ini dilakukan untuk memperoleh profil kompetensi guru yang bermanfaat sebagai salah satu dasar bagi kepala sekolah / madrasah dan / atau koordinator pengembangan keprofesian berkelanjutan untuk merencanakan program pengembangan keprofesian berkelanjutan yang harus dilaksanakan guru.

\section{SIMPULAN DAN SARAN}

Pelaksanaan supervisi akademik dapat meningkatkan kinerja guru, kinerja guru yang dimaksudkan dalam penelitian ini adalah kemampuan guru melaksanakan pembelajaran yang sesuai dengan Rencana Pelaksanaan Pembelajaran (RPP) yang dibuat dengan baik dan benar. $\mathrm{Hal}$ ini ditunjukan dari hasil penelitian pada kondisi awal tindakan rata - rata nilai kinerja guru dalam menyusun dan melaksanakan pembelajaran sebesar 63\%. Pada Siklus I setelah menerapkan supervise akademik nilai rata - rata kinerja guru dalam menyusun dan melaksanakan pembelajaran sebesar $79,89 \%$. Mengalami peningkatan sebesar 16 , 89\%. Pada siklus II diperoleh nilai rata - rata kinerja guru menyusun dan melaksanakan pembelajaran sebesar $88,33 \%$. Mengalami peningkatan dari siklus I ke Siklus II sebesar 8,44\%. 
Hal ini berarti terjadi peningkatan Kinerja guru dengan menerapkan Supervisi akademik dari kindisi Awal hingga Kondisi akir yaitu pada akir siklus II sebesar , 25,33\%. Dan sesuai dengan indikator peningkatan kinerja yaitu $25 \%$ maka penelitian ini dikataan berhasil. Penerapan Supervisi akademik dapat meningkatkan kinerja guru di SDK Waepana, Kecamatan Soa, Kabupaten Ngada TP 2018/2019 dinyatakan berhasil dan terbukti dalam penelitian ini. Dari temuan dia atas dapat disarankan hal - hal sebagai berikut.

Kegiatan supervisi akademik sangat baik dilakukan untuk membina guru meningkatkan kompetensinya. Sebaiknya kegiatan ini dilaksanakan secara terencana dan berkesinambungan. Sebaiknya pembinaan ini dilanjutkan dengan supervisi akademik dalam pelaksanaan pembelajaran untuk mengukur kemampuan guru dalam mengimplementasikan rencana pembelajaran yang telah disusunnya. Sebaiknya supervisi juga dilakukan terhadap semua guru secara bergilir dan menyangkut seluruh aspek kemampuan/ kompetensi guru seperti yang disyaratkan dalam permendiknas no 16 tahun 2007.

\section{DAFTAR PUSTAKA}

Arikunto, Suharsimi. 2006. Dasar Dasar Supervisi. Jakarta: Rineka Cipta

Ekosiswoyo , Rasdi dan Maman Rachman, Manajemen Kelas. Semarang: IKIP Semarang Press, 2000.

Ermelinda Yosefa Awe, 2014. Hubungan Antara Kualifikasi Akademik, Kompetensi, Motivasi Kerja Dengan Kinerja Guru Sekolah Dasar (Sd) Di Kecamatan Bajawa, Kabupaten Ngada. e-Journal Program Pascasarjana Universitas Pendidikan Ganesha Program Studi Pendidikan Dasar (Volume 4 Tahun 2014) https://media.neliti.com/media/p ublications/123152-IDhubungan-antara-kualifikasiakademik-kom.pdf

Handoko, T., Hani, 1998, Manajemen dan Sumber Daya Manusia, Yogyakarta, Liberty.

Parwati Santi Desak Putu, Dantes Nyoman dan Natajaya Nyoman. 2013. Implementasi Supervisi Akademik dalam Rangka Peningkatan Kemampuan Menyusun RPP pada Guru Matematika Sekolah Dasar Anggota KKG Gugus IV Kecamatan Sukasada .e-Journal Program Pascasarjana Universitas Pendidikan Ganesha Jurusan Pendidikan Dasar, di akses pada 5 Oktober 2018 
Pujiono. 2014. Laporan Pelaksanaan Supervisi Akademik. SD Kristen Satya Wacana.

Sahertian, P.A .2010. Konsep Dasar dan Teknik Supervisi Pendidikan dalam Rangka Pengembangan
Sumber Daya Manusia. Jakarta: Rineka Cipta

Sergiovanni, T.J. et al. 1987. Educational Governance and Administration. Second Edition. Englewood Cliffs, NJ: PrenticeHall, Inc. 